\title{
Ruptura y subversión en las novelas de Mauricio Wacquez: una propuesta de lectura a partir de la teoria escisionista*
}

\author{
Claudia Molina Jara**
}

\begin{abstract}
Resumen
El presente artículo es el resultado de un ejercicio crítico, esto es, leer las novelas de Mauricio Wacquez entendiéndolas como un proyecto escritura. Para esto, nuestra propuesta toma como punto de partida la metodología de cortes estratigráfico propuesto por Michel Houellebecq, aplicando a su vez la dimensión teórica contenida de François Meyronnis en L'Axe du Néant (2003), específicamente, el concepto de escisión en su escritura.

Palabras Claves: Nihilismo, Espectáculo, Literatura, Mauricio Wacquez, Escisionismo.
\end{abstract}

Breaking and Subversion in Novels of Mauricio Wacquez: a Proposal of Reading from Theory Scissionist

\begin{abstract}
This article is the result of a critical exercise that is, reading the novels of Mauricio Wacquez understanding them as a rupture and writing project. For this, our proposal takes as its starting point the methodology of stratigraphic cuts proposed by Michel Houellebecq, applying in turn the theoretical dimension of François Meyronnis contained in L' Axe du Néant (2003), specifically, the concept of division in writing.

Keywords: Nihilism, Entertainment, Literature, Mauritius Wacquez, scissionist.
\end{abstract}

\footnotetext{
* Este artículo forma parte de la tesis de Doctorado en Literatura Latinoamericana (Universidad de Concepción, Chile), en desarrollo, "Mauricio Wacquez: Formas de (DIS) Continuidad en la Narrativa Chilena", financiada y apoyada por la Comisión Nacional de Investigación Científica y Tecnológica, Conicyt. Recibido: mayo 2016. Aceptado: junio 2016.
}

** Universidad de Concepción. Concepción, Chile. Email: clamolinaj@udec.cl 
Desde que Mauricio Wacquez publica Cinco y Una Ficciones en 1964 hasta después de su muerte, en el año 2000, se registra un número importante de trabajos críticos de corte periodístico que hacen referencia a su obra y la importancia que ésta va adquiriendo a medida que se va desarrollando.

A luz de estos antecedentes, es que nosotros proponemos una aproximación a las novelas de Mauricio Wacquez y la crítica derivada de ellas, haciendo una lectura a partir de la dimensión teórica contenida en la reflexión de François Meyronnis en L'Axe du Néant (2003), a cerca de las formas de continuidad adoptadas por la literatura contemporánea. Así, nuestra hipótesis toma como punto de partida la situación actual de la literatura, esto es, una sociedad caracterizada por el espectáculo, en el contexto de una situación planetaria mayor: el nihilismo consumado, la que es transversal a todas las esferas del pensamiento. De modo que al leer las novelas de Wacquez podemos percibir el carácter revolucionario de su escritura, movilizada por un afán liberador del conservadurismo imperante, lo que permite perfilarlo en términos de Meyronnis (2003) como uno de los primeros escritores escisionistas, con un estilo único que fue evidente no sólo para sus lectores, sino también para quienes se refirieron a sus textos, en la época que escribió y en sus actuales relecturas.

Así, como un medio para demostrar nuestra hipótesis, es que hemos optado por dar una mirada profunda al objeto de estudio. Para ello, hemos aplicado la metodología propuesta por Michel Houellebecq en Intervenciones (2011). Ahí, a partir de la reflexión sobre la obra de Alain Robbe - Grillet, el autor explica, en términos técnicos, en qué consiste el procedimiento de cortes estratigráficos, el que ha sido extraído de la geología y aplicado a la agronomía:

¿Una vez cavada la zanja, que hacemos? Pues observamos. Es decir, que dibujamos con la mayor precisión posible, lo que vemos [...] Así, a través, del corte estratigráfico, el estudiante de agronomía se forma en esta austera disciplina consistente en considerar el mundo con una mirada neutra y puramente objetiva. ¿Y no es esto lo que Alain Robbe - Grillet intentó hacer más adelante en literatura? (Houellebecq, 2011: 225-256).

La utilización de esta metodología permite escoger fragmentos específicos en determinados segmentos seleccionados y poder explorarlos en profundidad, dando cuenta del fenómeno que queremos investigar, esto es, los elementos escisionistas presentes en las novelas de Mauricio Wacquez. 
una propuesta de lectura a partir de la teoria escisionista

\section{Desde el Nihilismo consumado hacia el Escisionismo}

Frente a la situación planetaria actual, esto es, el nihilismo consumado ${ }^{1}$ y la mercantilización de todas las esferas sociales y culturales, es que entendemos que la postmodernidad no sólo debe entenderse como una ruptura estética o un cambio epistemológico, sino como una señal cultural de un nuevo estadio histórico.

Guy Debord en su texto La Sociedad del Espectáculo ${ }^{2}$ plantea que se está frente a una sociedad que ha mercantilizado todas las esferas del pensamiento, dando paso a que la literatura sea considerada una mercancía más, obligándola a adoptar un estilo que la transforma en información. Resulta imposible sustraer a los escritores de una sociedad con estas características, donde "la finalidad no es nada, el desarrollo es todo" (Debord 2003: 12).

Aunque, los planteamientos de Guy Debord pudieran parecer extemporáneos, éstos adquieren nuevo sentido al contrastarlos con los de Mario Vargas Llosa, provenientes de su texto La Civilización del espectáculo (2012), los que no sólo son una forma de actualizar la problemática de la cultura como espectáculo, sino también, una manera de acercarnos a la reflexión desde Latinoamérica, dando cuenta de la metamorfosis que ha experimentado el término cultura: "un mundo en el cual el primer lugar está ocupado por el entretenimiento y la frivolidad prolifera haciendo estragos en las mentes de las personas" (2012: 26).

$\mathrm{Al}$ respecto, Frédéric Badré, en su libro L'avenire de la littérature (2003) realiza una reflexión crítica del presente de la literatura francesa que es posible aplicarla a la literatura en general, en un contexto en que, según Mario Vargas Llosa, la globalización ya no es una tendencia, sino una forma de vida más. Según Badré, la única chance u oportunidad posible sería plantearse de

\footnotetext{
${ }^{1}$ Entendemos el Nihilismo Consumado, a partir del libro Gianni Vattimo El Fin de la Modernidad. Nihilismo y Hermenéutica en la cultura Posmoderna (1987), donde se discute ampliamente el concepto de nihilismo a partir de los planteamientos de Frederich Nietzsche y Martin Heidegger. Según Vattimo, el nihilismo está en acción, puesto que ha traspasado todas las esferas del pensamiento, de modo que resulta imposible hacer un balance de él, no obstante, y en palabras del mismo Vattimo : "...se puede y se debe tratar de comprender en qué punto está, en qué nos incumbe y a cuáles decisiones y actitudes nos llama." (1987:22) De esta manera, el mismo autor plantea que la posición que se debe adoptar frente al nihilismo consumado, como lo plantea Nietzsche, es la de aquel que comprendió que el nihilismo es su única chance $u$ oportunidad, en la medida que puede implicar la única salida de esta situación planetaria actual, estática y repetitiva. En tanto, la acepción de nihilismo propuesta por Heidegger plantea que se está frente a un proceso donde al final, "ya no queda nada". En otras palabras, ambas definiciones plantean que el nihilismo consumado es la situación final en el individuo, donde ya NADA queda. Pero que en palabras del mismo autor, al ser nuestra última oportunidad: "....nos llama a vivir una experiencia fabulizada de la realidad, experiencia que es también nuestra única posibilidad de libertad." (1987:32)

2 Debord, Guy, La Sociedad del Espectáculo. 1967. Valencia: Pre-textos. 2003

${ }^{3}$ Frederic Badré forma parte de un grupo de escritores reunidos en el proyecto de la revista Ligne de Risque, fundada en 1997 y que agrupaba a un grupo de intelectuales de franceses donde se encontramos, también a Yannick Haenel, Francois Meyronnis y Philippe Sollers. Ellos definen su proyecto como una "central de energía" que focaliza su trabajo en reabrir la historia de la literatura frente a un nihilismo planetario cumplido que pretende situarse de manera crítica a la mercantilización dominante.
} 
manera extrema frente al nihilismo consumado, es decir, partir de cero como ya lo había planteado Gianni Vattimo $(1985)^{4}$, de modo de traspasar la línea del nihilismo.

Mais il s agit de repartir à Zéro, de TOUT reprende, en tenant compte sérieusement du nihilismo planétaire. Tout reprende pour franchir la ligne du nihilismo. Ainsi l'avenir sera-t-il donné". (2003: 122).

En la línea de pensamiento propuesta por Badré, un libro posee un valor en sí mismo por la fuerza del pensamiento que él implica y la poética contenida en él. Así, para el autor, hacer literatura implica una dimensión subversiva, un acto que trasciende la línea del nihilismo, en palabras de Vattimo (1985), es una chance u oportunidad de soslayar la línea o barrera del nihilismo.

Es en este sentido, que entendemos la obra de Mauricio Wacquez, como una forma de resistencia, en su ensayo La Cultura como Seguridad de $1972^{5}$, percibió que el cambio del rol de la cultura sería nocivo para las generaciones posteriores y daría lugar a una nueva forma de entender al mundo.

Digámoslo de una vez: hemos nacido y vivido en un mundo crítico. En el momento en que tratamos de echar una mirada inteligente al mundo que nos rodeaba, nos encontramos con el panorama asombroso de vivir una vida absurda (Wacquez: 1972: 6).

La postura adoptada por Wacquez adquiere significado al aplicar los planteamientos de Françoise Meyronnis en L'Axe du Néant (2003) para quien pensar, significa luchar contra la imposibilidad de pensar, es decir, es un acto de subversión, a partir del vacío desde donde emerge una libertad salvaje, que posibilita la creación, dando paso a un concepto acuñado por el mismo Meyronnis: Escisionista, es decir, una persona que no teme salirse de lo establecido, que no admite comunidad, que es capaz de problematizar el circuito que rodea el pensamiento y posibilita la invención de nuevas formas. El acto escisionista se define, entonces, como un movimiento que permite salir de la comunidad esclavizada por los modelos imperantes y una forma concreta de traspasar la línea del nihilismo hacia: "Là où est le danger croît aussi ce qui sauve" (2000: 60).

Un escisionista, según Meyronnis, toma una posición contraria u opuesta al modelo imperante, ubicándose en el eje de la Nada, desde donde escribe y desde donde el arte es posible; dando paso a una escritura que surge desde el enfrentamiento con una experiencia de la Nada como una salida a la situación actual.

\footnotetext{
${ }^{4}$ Vattimo, Gianni. El Fin de la Modernidad. Nihilismo y Hermenéutica en la cultura Posmoderna, Barcelona: Gedisa. 1987

${ }^{5}$ Wacquez, Mauricio. Cultura como Seguridad, Colección Escritos Breve del Departamento de Filosofía de la Universidad de Chile Santiago. 1972
} 
Toutes les littératures de tous les temps sont là, sur la table, comme elles ne l'ont jamais été à aucun moment de l'histoire (2000: 237).

Meyronnis elabora sus ideas a partir del diálogo con el pensamiento de Debord, fundamentalmente en relación a la sociedad del espectáculo, donde el lenguaje se reduce a un mero vehículo de comunicación, desprovisto de sus otras dimensiones, entre ella la dimensión poética del lenguaje.

Desde estos fundamentos teóricos, es posible entender cómo Mauricio Wacquez flanquea la barrera del nihilismo y va más allá de la parálisis, a partir de una escisión, una ruptura que permite un desbloqueo, una salida al nihilismo, dando paso a una nueva forma de expresar temas tabú, mediante un lenguaje formal, erudito, poético, desprovisto del morbo y la carga comunicacional que es parte de esta nueva sociedad del espectáculo. De esta manera, tal como hemos planteado creemos que Mauricio Wacquez percibió esto como una salida, transformándose en un escisionista, lo que le permitió una oportunidad única: la de forjar un proyecto de escritura propio y aparte de los demás.

\section{Mauricio Wacquez y su escisión}

Los estudios literarios en América Latina son un tema largamente discutido y que Mauricio Wacquez intenta desarrollar, manteniendo una postura escisionista frente a este tema, en un contexto que a priori resulta adverso, ya sea por el conservadurismo de la época en la escribe o por las circunstancias políticas que son un elemento fundamental en la época en la que escribe. Al respecto, cabe mencionar, que Wacquez manifestó una cercanía con las tendencias revolucionarias y socialistas del momento en que escribió, viajó a Cuba y publicó ahí La Cultura como Seguridad, no obstante, en sus novelas se aleja de los temas políticos-sociales comprometidos y se acerca a temas más íntimos personales, lo que a nuestro juicio forma parte de la subversión y una escisión con el momento político de la época.

En este sentido, Wacquez busca y elabora una forma de abstraerse de la crítica tradicional, por medio de una narración particular e interior que revela un conflicto personal. Así, la crítica en su incasable búsqueda de "la verdad", del "único y verdadero" significado de los textos, realiza lecturas marcadamente morales o pedagógicas, a través de discursos moralizantes, carentes de ética y que, además, responde a las necesidades del marketing editorial, que sólo busca vender. Esta actitud de los críticos tradicionales ha hecho de la crítica un ejercicio que ignora el proceso creativo, lo que en el contexto de la literatura francesa y producto del nihilismo consumado se manifiesta, según Meyronnis, en el advenimiento de una defensa "hipócrita" a la crítica, centrada en lo exclusivamente promocional, que pone a la literatura y a las artes en general en una situación compleja y extrema, que ignora lo diverso.

De modo que al contrastar este nuevo escenario con la prosa de Mauricio Wacquez, logramos entender que no haya existido un interés en leer sus li- 
bros y en hacer una crítica más académica, en el momento que él escribió. De hecho a lo largo de nuestra investigación, hemos podido advertir los escasos trabajos críticos académicos sobre sus textos, donde destacan el de Francisco Robles, An-atomía/Desaparición del cuerpo en Excesos, de Mauricio Wacquez, publicado el 2004 y el de Lorena Amaro Castro, Wacquez y sus precursores: infancia, género y nación del 2014.

Lo anteriormente, al parecer, no provocó gran tribulación en Wacquez quien manifestó, en reiteradas ocasiones, que no se sentía parte de la generación en la cual se le clasificó, además expresa de varias maneras el carácter individual y personal de sus textos: "Soy un escritor de minorias y nunca he aspirado a ser otro tipo de escritor. Reconozco que mi literatura es absolutamente minoritaria. Que le gusta a ciertos amigos y sigo diciendo que escribo para mis amigos" ${ }^{\prime \prime}$. No hay necesidad de sentirse un escritor de masas, Wacquez acepta su posición de escritor "minoritario", busca el respaldo de sus pares escritores-amigos de los cuáles proviene gran parte de la crítica existente y disponible, de modo que es posible establecer que el autor asume la existencia de un destinatario culto y letrado, que se deleita con la técnica literaria utilizada, ese es el lector imaginado por Wacquez.

$\mathrm{Al}$ respecto, Jorge Edwards, amigo del escritor, plantea:

Ya está lejos de la seguridad narrativa de generaciones anteriores. Lejos del realismo mágico de un Asturias o un García Márquez, o del relato fantástico practicado por Borges o Bioy Casares. Uno desearía que el autor no se deje arrastrar por la tentación del magma verbal, en que algunos escritores de su edad, sobre todo en Francia, han naufragado. Hasta aquí incorpora el "exceso" intelectual y erótico de un mundo novelesco de un equilibrio bien logrado, que no recurre nunca, para citar un ejemplo, a los neologismos o a la incoherencia. Wacquez probablemente pensaría que introduzco aquí una reserva conservadora, y quizás tenga razón, pero en lo que pienso, al decir esto, es en su posibilidad de seguir escribiendo novelas. Frente a un hombre armado es un libro «radical», en el sentido estricto de la palabra; por eso pone la posibilidad misma de la novela en tela de juicio, y por eso es un libro extremadamente inquietante?

Lo anterior se acentúa cuando se advierte que una parte importante de su obra es publicada fuera de Chile, excluyéndolo de instancias institucionales académicas nacionales, que él mismo considera decadentes, lo que queda de

\footnotetext{
${ }^{6}$ Aguilera, Claudio:" Mauricio Wacquez la muerte de un escrito olvidado". Diario La Tercera, Santiago, 19 de septiembre del 2000.Disponible en http://www.letras.s5.com/artwacquez1.htm

${ }^{7}$ Rastros de sus Libros: Lo que se dijo sobre la obra de Mauricio Wacquez en distintos medios, Edwuars, Jorge. "El Mercurio", 30 de agosto de 1981. Disponible: http://www.letras.s5.com/wacquez3.htm (Visitado: 24 de septiembre de 2015, 11:07 a.m)
} 
manifiesto en las menciones que se hacen a la Generación del 50 en la novela Epifanía de una sombra, la que denomina irónicamente como "Los Cincuenteros":

La concurrencia se fue aplacando hasta que los murmullos se redujeron a sillas que se corrían, a carrasperas, a toses. Quedó entonces el ánimo en suspenso antes que el creador de los cincuenteros comenzará a hablar (Wacquez, 2000: $373)$.

Al constatar el rechazo a la generación anterior, se entiende por qué se excluye de instancias nacionales académicas asociadas a la edición y difusión de su obra. Podemos comprender que su opción de publicar fuera en editoriales reconocidas, tales como Bruguera, Tusquets, entre otras, le permite moverse funcionalmente y no de manera elitista. Esta práctica permite que sus textos sean leídos y valorados desde lo estético y no desde lo espectacular. Esto conlleva el costo de ser casi un desconocido en su propio país, pero por sobre todo, morir en suelo ajeno añorando volver: "Me encantaría tomar mis bártulos y volver. O hacer medios pollos aquí y allá. Me he reenamorado de este país y de una manera loca"8. Lo que queda de manifiesto en sus novelas, por ejemplo, en las descripciones que se realizan de Ñilhue en su último texto, que remiten a Cunaco de Vélez en el Valle de Colchagua, su tierra natal, las que están cargadas de detalles exuberantes y cuidadosos.

Pero por detrás se extendían los campos infinitos, las infinitas viñas, cortadas por hileras infinitas de álamos, y al otro lado, derivando hacia el río, una consecución de potreros, también infinitos, rebosantes de pastos y plantados con árboles que les daba nombre a cada uno (2001: 39).

En cuanto al estilo narrativo de Mauricio Wacquez, la crítica constantemente destaca que él es poseedor de un estilo único y particular, no obstante, a raíz de los antecedentes que hemos recolectado en esta investigación, creemos que es posible caracterizar su escritura con rasgos entrópicos, es decir, en sus textos el orden y el desorden se presentan no como opuestos uno a otro sino como elementos indisociables y complementarios el uno del otro.

Respecto a la entropía, Noe Jitrik la ha definido como una forma que adquiere el desorden, generando movimientos internos, lo que posibilita cierta forma de orden. Jitrik alude que este desorden o caos aparente se canaliza a través de la escritura y corresponde a una forma de visualizar un sistema de saberes o códigos que están en una "producción incesante que da lugar a una sobrecarga de esbozos de sentidos" (2000: 58), lo que provoca un desorden continuo, que Jitrik denomina espacio entrópico, es decir, la irrupción de las

\footnotetext{
${ }^{8}$ Aguilera, Claudio: "Mauricio Wacquez, la muerte de un escritor olvidado", La Tercera, 19 de Septiembre del 2000. Disponible en http://www.letras.s5.com/artwacquez1.htm (Revisado: 24 de septiembre de 2015, 12.47)
} 
sensaciones del escritor. En el caso de Wacquez, esto se traduce en la añoranza del otro, por ejemplo, las constantes referencias que hace Max acerca de Marcelo, en Toda la Luz del Mediodía.

Al recordar, hoy, esos momentos, trato de precisar en mí lo que en esa época llamaba mi felicidad al lado de Marcelo. Un sentimiento que hoy es bastante impreciso, pero que me viene por etapas, acompañado de estremecimiento (Wacquez, 1964: 63).

Marcelo, a mi lado, estaba echado de espaldas con los ojos cerrados; tenía las piernas encogidas y los brazos por debajo de la nuca [...] Pensé que podría permanecer toda la vida así, sin despertar, en la perfección cálida del día. Pero de pronto abrió los ojos y miró alrededor [...] Se hizo rodar con todo el cuerpo y quedó junto a mí, inmóvil, respirando suavemente. Yo le veía una parte del cuello que bajaba limpia hasta las clavículas y subía en un ángulo torcido perdiéndose en el pelo castaño. Lo rodeé los hombres y lo atraje dulcemente hasta mi cara (Wacquez, 1964: 75-76).

$\mathrm{O}$ el recuerdo que de Alexandre en Frente a un Hombre Armado.

Entonces es Alexandre. Cuando un plañido desgarra mi garganta, es Alexandre que toma el lugar que le corresponde, cuando la muerte cae sobre mí y me convierte en un objeto entre los objetos, un desierto por donde podría pasar eternamente la arena sin prefigurar un particularismo reconocible (Wacquez, 1981: 52).

Pensé en Alexandre como en el verdadero destinatario de mi puesto; sentí una inexplicable dulzura al imaginarlo cuajado de luces y de oros, hiriéndome en el corazón con un dardo o una espada, como en las tragedias antigua, donde el déspota encuentra en el derrocamiento y la muerte el verdadero sentido de su gloria (Wacquez, 1981: 135).

Este depósito de imágenes "masa de imágenes acumuladas en desorden" (Jitrik, 2000: 58), no surgen arbitrariamente, sino que se expresan mediante la "exterioridad" del sujeto, por medio del desorden individual que asoma del personaje, transformándose en una acumulación de imágenes que se van desencadenando en la escritura (Jitrik, 2000: 60), lo que en el caso de Wacquez se manifiesta de diversas formas: en las añoranzas del otro, en la manera como se relata la historia la que no sigue un hilo narrativo lineal, sino más bien se deja llevar por el flujo de la memoria y por recuerdos que emergen de manera desordenada, como en el caso de Frente a un Hombre Armado y Epifanía de una Sombra.

Mención aparte, merece en este punto la novela Paréntesis (1974) cuya narración rompe de manera categórica el orden lineal de los hechos, además este desorden entrópico es tal, que en algunos casos las voces de la narración pasan de la primera persona a la tercera y viceversa, creando una idea de 
vértigo en el lector que debe, en algunos casos, retomar la lectura a fin de comprender a quien corresponde lo dicho, aun cuando, esto podría resultar agotador, la historia logra conectarse.

[...] yo aceptaría esa agresión sin chistar, sin rechazarla ni oponerle mi fuerza, mi virilidad satisfecha e indefensa, aunque lentamente, esa virilidad que es mía, se despertaría y querría rechazar y oponerle su fuerza esa agresión, Renata vio que Bruno entreabría los ojos y se pegaba a ella, vio como su rostro desaparecía detrás de su cuello (1974: 35).

Jitrik menciona que cuando se produce un quiebre del equilibrio entre la visualización de lo exterior y de lo interior se da origen a lo denominado por Julia Kristeva "interferencia depresiva", lo que significa que el saber y la imagen caen ante este desnivel depresivo. El escritor enfrenta esta depresión inicial con la "decisión" de inaugurar la escritura, desde el punto de vista de Jitrik: "la escritura es una respuesta al caos" (2000: 69).

Esta interferencia depresiva se manifiesta en las novelas de Wacquez de diversas maneras en sus personajes, los que contantemente hacen referencia a la soledad o la frustración en la que están inmersos:

En ese tiempo, recuerdo, jugaba a sentirme solo. No sabía del tiempo que vendría después; no conocía la duda de desaparecer, del abismo de una noche que se demoraría por siempre (Wacquez, 1964: 76).

[...] esa es la verdad de lo que soy: un extranjero en mi propia piel, que no pertenece a nada ni a nadie, que no es dueño de ningún bien y que, además, no ha logrado la felicidad del corazón y por eso mismo es feo y egoísta, un ser que es presa de todos los males que acompañan la desdicha, porque en verdad, no es que estas cosas vengan de mí, sino que la forma como se manifista mi infelicidad (Wacquez, 1975: 56).

Aunque ahora pienso que esos reveses me hicieron ser todo lo que soy, es decir, ese único ser conocido más o menos bien que, por eso mismo, puede ser él y muchos (Wacquez, 1981: 35).

No es fácil reconocer los fracasos, sobre todo los primeros: ese reconocimiento lleva implícito el incómodo trabajo de rehacerlo todo (Wacquez, 1983: 107).

Desde entonces, las borrosas sendas que deja el barco en el mar, le han producido siempre una deliciosa sensación de extravió, de girar en redondo, de vagar por el camino a ninguna parte. Esta sensación tan poco provechosa, como una puridad viva, de un mero gozo, ha hecho de él este perdedor que mira embobado las ruinas que lo rodean (Wacquez, 2001: 149).

Al respecto, José Promis plantea que las novelas escritas en este periodo son parte del programa Novela de la Desacralización cuyo proyecto se centra en la subversión o negación radical de las categorías estéticas de representación de las generaciones anteriores, a partir de la desconstrucción de los 
modelos en la conciencia del lector, es decir, una actitud rebelde con tendencia hacia la introversión, lo que se manifestó en torno al motivo de la búsqueda del orden dentro del caos, que asumía la forma de un escrutinio narrativo. Así, los textos son el resultado del proceso de introspección artística y no una larga representación de hechos. Narrar es ahora el equivalente a exteriorizar los conflictos interiores, se trata más bien de un proceso de escritura que revela el estado interior, los conflictos, la soledad, la necesidad del aislamiento. Así, enunciar pierde cualquier sentido moralizante o pedagógico, para transformarse en un relato doloroso y complejo con el cual se pretende reencontrar un balance en el mundo que lo rodea.

Toda la luz del Mediodía (1965) inicia al amanecer de un día de verano, donde el narrador y protagonista comienza el relato de la historia: con la frase: "Voy a contar algo" (1965: 07), mediante la utilización del pronombre indefinido "algo", el narrador expresa lo indeterminado, lo innombrable de su historia, esto es, la disyuntiva entre Marcelo o Paulina y, al mismo tiempo, revela a un narrador que intenta exteriorizar el conflicto, en busca del restablecimiento del equilibrio necesario, por lo que hay una elección cuidadosa de las palabras que dan cuenta de los hechos, diferenciando los esenciales de los accesorios.

La organización del discurso permite advertir que el narrador y el protagonista se desdoblan, transformándose en receptor de su propio texto, opinando sobre él, lo que permite reflexionar en el proceso de escritura y hacer una elección de lo que se va a narrar: "¡Pero cuánto rencor podría poner yo en mi relato! No obstante, me resisto a hacer esto. Mi voluntad puede más que mi egoísmo" (1964: 32).

Uno de los quiebres más significativos de la novela, es la ausencia de acontecimientos narrados, el texto hace un recorrido por una serie de momentos e imágenes provenientes del pasado, hace referencia a las "largas conversaciones" con Paulina que no se transcriben en la novela, se centra en la descripción de las sensaciones íntimas y en evocar los recuerdos de Marcelo, que irrumpen de manera sorpresiva en el relato, llamando la atención, dando a entender una relación homosexual, lo que expresa el profundo quiebre, la escisión con las temáticas de la época, si bien no expresa de manera directa la relación entre Max (el narrador) y Marcelo, hay constantes alusiones que están representadas con un lenguaje poético, cargado de metáforas, con una sintaxis simple, que no incomoda a quien lo lee, sino que más bien cautiva por la sutileza y precisión en el uso de las palabras.

Porque tu existencia es necesaria y suficiente para que la mía ansíe la quietud, para que crezcan los árboles y los rincones de esta casa adquieran sentido, para que todo se una y teja nuestro orden; lejos de los rostros, de los gestos, de las miradas vacías. De manera que el sol no moleste la intimidad de las cavilaciones. Así adivinaré fácilmente lo que piensas, y cada gesto tuyo será una prolongación hacia mi vida (Wacquez, 1965: 14). 
Desde que llegó la primavera comencé a gozar con la excitación de respirar, de moverme, de acariciar mi piel bajo la luz de la mañana. Y estas excitaciones confirmaron, como yo lo suponía, los presentimientos de antes, en el sentido de que cada nueva sensación me hizo recordar un momento de Marcelo, un gesto suyo, el olor de su piel (Wacquez. 1965: 134).

Este distanciamiento temporal entre los recuerdos y el momento de la narración, así como la irrupción de estos recuerdos de manera fragmentada permite que la construcción del relato sea tarea del lector, en la medida que se compromete con la lectura. Al inicio, el receptor puede sentir cierta extrañeza por la irrupción incomprensible de algunos hechos, pero paulatinamente la lectura deja de ser enigmática. No obstante, lo anterior, permanece la ambigüedad, ya que hace dudar al lector acerca de que lo leído sea efectivamente lo que él piensa y no otra cosa.

El lenguaje adquiere la dimensión de un instrumento cuidadosamente elegido, al servicio de la exteriorización del conflicto del autor, que a la postre no es un conflicto moral, sino un conflicto personal entre dos relaciones: una heterosexual, tranquila y otra homosexual mucho más pasional, finalmente, el conflicto se resuelve, el narrador hace una elección que deja una sensación de alivio y resignación, pero al mismo tiempo deja atónito al lector: "Seguramente el orden se puede encontrar en cualquier parte" (1965: 160).

En 1974, su segunda novela Paréntesis concita un alto nivel de atención, logrando incluso ser finalista del Premio Barral del mismo año, la novela muestra los amores entre Renata, Bruno, Roger e Isabelle: Bruno está enamorado de Roger, y éste es el amante de Renata.

La novela capta la atención por su estructura, presenta la narración en una sola oración inserta en un paréntesis, donde el fluir de conciencia y los recuerdos siempre cambiantes de los cuatro personajes se intercalan y atropellan, dificultando el reconocimiento de los discursos, pero no la comprensión del texto mismo.

Paréntesis es una novela experimental con una técnica literaria rupturista y con un lenguaje cercano a la poesía, lo que lo hace más atractivo para el lector, dado que la novela da lugar a espacios abiertos, llenos de encuentros, desencuentros, de complicidades, de cariños opresivos, asfixiantes, que evocan sensaciones en la persecución del amor y el irreprimible deseo sexual, que nuevamente pone de manifiesto el autor, a través de relaciones homosexuales y heterosexuales.

[...] Sentía correr mi sangre en pulsaciones aceleradas, entonces te tomaba y esa sed lograba calmarse por un instante, mi cuerpo se aligeraba y, por cierto, recordaba la paz, sin embargo, el que yo sintiera esa lasitud de mi virilidad satisfecha ¿calmaba en algo esa otra sed más vieja que cualquier deseo? (Wacquez, 1974: 90). 
De esta manera es posible establecer el texto, no sólo como una novela escisionista desde el punto de vista del tema, sino también desde el punto de vista de la narración, que llama la atención desde el prólogo de José Donoso, quien presenta la novela como el mero espacio de una acotación, un paréntesis, la coincidencia de los cuatro personajes, que logran que el intercambio lejos de confundirse, establezca contrapuntos, fugas, complicidades, que van más allá del simple relato, dejando claro el fluir de la conciencia de cada uno, que revela intenciones, gustos, pasiones y disgustos. Lo único que no alcanzan es la coincidencia en un diálogo o en un recuerdo.

La historia que se pretende narrar está siempre más allá de la narración, en un pasado compartido, que se intenta sintetizar vanamente, dado que las otras voces intentan contarlo todo en una palabra. Wacquez se sitúa en el límite de la experiencia literaria del fracaso, puesto que no es el amor el problema de los personajes, que aman de manera extrema, sino el vacío que deja la imposibilidad de concretarlo.

Bruno, mientras come, no se digna a mirarme ni recordar, encerró dos días en su memoria en un lugar parecido a la muerte, sin claridad, sin aire, esos días no existieron, simplemente, yo no tengo la culpa, yo lo rechacé por ser mi hermano, haciéndole creer que seguía siendo mi hermano y que nuestro amor sería castigado con un fuego más terrible que el fuego eterno [...] (Wacquez, 1975: 45).

Yo era vulnerable y estaba desprovisto de sentido real, sentía desplegarse tu amor junto a mí y lo comprendía a partir de lo que yo sentía, entonces me emocionaba y se me salían las lágrimas o me iluminaba la dicha, cosa que tú confundías con amor [...] (Wacquez, 1975: 87).

En 1981 se publica la novela Frente a un hombre armado, ambientada en Francia a mediados del siglo XIX. Juan de Warni es el protagonista del texto, cuya experiencia erótica es determinante, sobre todo en la metáfora central del libro: la de la caza que produce vértigo a medida que se va generando la inversión, ya que el mundo estructurado se voltea; el cazador es la víctima, y el mundo de la víctima no es el mismo. De este modo, las preferencias sexuales del protagonista aparecen como la transgresión básica a los fundamentos de cualquier código, afecta los gestos básicos mediante los cuales el individuo se relaciona con el mundo, se transforman en una subversión total, que implica un quiebre con lo impuesto no sólo con su familia, sino con su entorno.

La novela se configura como la biografía, real e imaginada de Jean de Warni o Juan Guarní, de su sirviente enamorado Alexandre, de sus padres latifundistas y de su preceptor M. Albert. Ambientada en 1847, el texto tiene, en primera instancia, la forma de un peregrinaje hacia el recuerdo, que determinó el inicio de una serie de transformaciones en el protagonista. La historia se presenta cargada de recuerdos, excediendo el ámbito de las memorias, contradiciendo todos los límites del personaje, haciendo patente el juego de 
inventarse el recuerdo posible que abre otro espacio imaginario, finalmente la intensidad de sus escenas y la atormentada pasión dan cuenta del amor prohibido, de los abusos del poder y del comportamiento criminal que desencadena el protagonista.

Si bien en primea instancia la novela se definió como un Bildungsroman, al leerla en profundidad es posible advertir que la novela de Wacquez subvierte el modelo de la novela de formación, dando paso a una escisión con el género, en la novela de Wacquez estamos frente a un protagonista que no ansía la aceptación, sino marcar la diferencia a través de la realización de un proyecto propio subversivo: dar rienda suelta a su interioridad, liberarse de lo que le impide amar a al otro. Así, la inversión sexual aparece como la transgresión del individuo que se relaciona con el mundo de manera conflictiva, dado la falta de autenticidad del mundo que le rodea, lo que queda de manifiesto con el juego liberador de la Musaraña, que representa la única salida para una realidad inmersa en la apariencia. Así, el aprendizaje va más allá, llegando incluso a una transformación total no sólo de Juan, sino también la de otros personajes, por ejemplo, el joven Alexandre.

Juan golpeó con el puñal el cuerpo desmadejado, pero, al sentirse herido, este se incorporó lo suficiente como para apoderarse del cuello de esa muñeca dislocada y a punto de morir que él había poseído. Apretó, y en ese instante comenzaron a sucederse las escenas que conocemos (Wacquez, 1981: 248).

Esta transformación provoca otra inversión, la de los roles del cazador y la presa, tal como lo indica el subtítulo del texto: "Cacerías de 1848", Juan de Warni se instala como cazador, en tanto que su presa es representada por Alexandre:

La caza, como ejercicio del poder, ilumino el paisaje del crimen. No son idénticos, son cómplices. Ambos dirimen sus problemas sin mezclarse con ellos. Los elimina. Como la guerra la caza un fin simple y trágico: la muerte de la presa. Ser sodomizado, en cambio, se emparenta con ambas actividades, pero como en una paradoja (1981: 97).

Pero un día hizo calor, y Juan se desnudó en el lago y no permitió que Alexandre hiciera lo mismo. Se desnudó ordenándole al muchacho que permaneciera vestido junto a la orilla; se sintió libre por primera vez [...] le hizo descubrir los vericuetos más secretos de la belleza de Alexandre, porque lo importante de eso era el cuerpo desnudo que aparecía dibujado en el rostro estático de su víctima, el cuerpo poseído ya por la avidez incontenible, el misterio que transforma a Alexandre en espejo de su propia trampa (1981: 197).

Y no lo digo por mí, a quien la contención y la astucia me permitían regular hasta los menores detalles del entusiasmo, sino por Alexandre. Un día inclusive tuve que azotarlo con la fusta para que volviera a ver en mí a quien correspondía (1981: 198). 
Sin embargo, esta dicotomía cazador/presa es parte de otra de las escisiones del texto, ya que a medida que el juego de seducción avanza entre los jóvenes, entre el señorito y su sirviente, la relación va cambiando, el seductor deja de ser tal y pasa a ser seducido, una presa de este sirviente que ahora ejerce un poder ante su señor, que cada día desfallece más ante la imposibilidad de mantener este juego de poder.

Una vez más, digamos que todo hombre de poder -y Juan no dejaba de ser uno- posee la contrapartida de su naturaleza en la seducción de la derrota (1981: 194).

Pero la desnudez de Alexandre era casi perfecta. Bajo sus ropas descuidadas había un cuerpo liso y bronceado que rechazaba lo superfluo [...] El no se avergonzaba en cambio de lo único francamente diverso entre nosotros: del bamboleo exasperante de su sexo (1981: 198).

No obstante, la sumisión de Juan y el hecho de haber logrado en parte su objetivo, llevó a Alexandre a iniciar una furiosa agitación, por la que se retiraba casi del todo y volvía a sumergirse hasta colmar nuevamente a su víctima (1981:237).

Juan de Warni constata desde muy temprano su diferencia y su necesidad de cambiar y modificar la cotidianeidad que lo rodea, lo que provoca un extrañamiento, un distanciamiento con la familia, específicamente con su padre, lo que lo desintegra, lo desmorona y lo hace caer enfermo:

Sería como reprocharle a León el hecho de haber sido mi padre, en un tiempo en que la paternidad más tenía que ver con la herencia de casta que con las particularidades de un rostro. Su condición de hidalgo aburguesado en las especulaciones argelinas, su rápido enriquecimiento y su necesidad maniática de perdurar en una historia (1981: 17).

Tendido en una silla de reposo, en el fondo más oscuro de mi habitación, repasaba los detalles de mi pasado, buscando la trizadura, el accidente que me había convertido en ese personaje irreconocible. Por eso concebí el proyecto de esta crónica, para averiguar en los pliegues menos visibles de mi vida las razones que me arrojaron fuera de la órbita trazada (1981: 85).

Desde esta nueva perspectiva asumida por Juan, se expresa una nueva manera de asumir la diferencia a partir de los recuerdos y las experiencias acumuladas en ellas, es ahí donde el personaje encuentra la identidad añorada y por tanto tiempo buscada:

De esta manera, la patria, las orillas, la lengua, no han sido más que momentos de las tantas patrias, lenguas y orillas que he vivido. No quiero decir que haya pretendido nunca abandonar el lugar de nacimiento. La prueba está en que hoy lo necesito y lo busco. Pero, al fin, ese lugar no se abandona jamás si por un territorio entendemos un recinto no mayor que un jardín, que un corazón o que 
una inteligencia. El verdadero exilio es la ausencia de claridad, la incuria, la estupidez. Para mí, la patria ha sido muchas veces un rostro, una melodía, una llanura de olivos ventilada por el aire lleno de celajes. También, y sobre todo, ha sido un agua (1981: 197).

Respecto al lenguaje, éste es envolvente por la simpleza y fluidez de su sintaxis, que cautiva sin empalagar por la cruda exactitud de las descripciones o su multiplicidad de recursos sensoriales y sinestésicos, lo que a lo largo de nuestra investigación se configura no sólo como un recurso más, sino como otro mecanismo escisionista, ya que con esto logra establecer notables diferencias de estilo narrativo, respecto a otros escritores de la misma época, que optan por un estilo más explícito, en el caso de Wacquez su lenguaje permite aceptar incluso las escenas más violentas y dolorosas, ya que el dolor descrito en cada una de ellas permite empatizar con el personaje de Warni:

Quise entender, fuera del ardor del sueño, por qué la muerte puede ser deseada como forma eminente de placer (1981: 46).

[...] yo quiero saberlo, adentrarme en el oscuro subsuelo, quiero descifrar ese rostro que aún tiene rasgos y ejercer el mando desde dentro, desde el corazón de su ley (1981: 62).

Así, la vida de Juan de Warni se manifiesta sin rodeos, encontrando su culminación en el acto sexual, donde las experiencias anteriores convergen en el ahí, a través de un lenguaje límpido sin asomo de vulgaridad o cursilería. Los actos sexuales en los que participa Juan de Warni, reales o imaginados, intentan, al parecer, exacerbar el placer del lector, dando lugar a una descripción acuciosa que tiene como centro lo sinéstesico, específicamente las texturas, las temperaturas, los aromas, entre otras sensaciones:

Pero, entonces, ¿quién era yo para Juan?, ¿yo era tal vez una mujer? [...] Él escuchó lo que yo pensaba, pues me aferró la mano obligándome a moverle la piel de atrás adelante mientras sus manos deshacían los botones de mi cintura y me bajaba de un golpe el pantalón y el calzoncillo, dándome vuelta [...] Sentí el extremo del cuerpo embistiéndome por detrás. Presa de un pánico y de una delicia indescriptible, me pareció que un molusco tibio y resbaladizo trataba de invadirme, un tentáculo trémulo y duro que debía cobrar la inferioridad que yo había reconocido en mi (1981: 141-142).

Otro elemento recurrente es el de la simulación: todos fingen en algún momento estar enmascarados; nada ni nadie es reconocible, ni es quien dice ser. El disfraz y la máscara ofrecen al sujeto la posibilidad de encontrar una identidad, nueva y diferente, los que una vez puestos constituyen un personaje que posibilita la liberación de las apariencias. Juan de Warni experimenta el desequilibrio, provocado por la inestabilidad de la metamorfosis del juego, 
lo que lo sumerge en una sola certeza: él sabe que no es quien dice ser a los demás, es decir, en el juego con la máscara hay una verdad, que entrega una certeza, posibilitada por el acto de fingir.

Uno de estos juegos de simulación es la Musaraña, el que adquiere especial importancia, a partir de la relación que establecen sus participantes, lo que hace pensar sobre las verdaderas identidades, que se ponen en entredicho. El juego consiste en ponerse una máscara, un sombrero, un disfraz, o hacer un simple gesto, que le permita al sujeto convertirse en otra persona, abriendo el mundo de la simulación y a la vez de la liberación que implica ser otro: "en que cada uno representaba el papel del otro, para así liberar el rencor que ocasiona el hecho de vivir juntos en un mundo cerrado y aburrido" (p. 29).

Esta instancia surge en un mundo cerrado, como una vía de escape, la posibilidad de una libre representación de personajes que van desde reyes hasta prostitutas, pasando incluso por el intercambio de roles entre ellos mismos, como cuando Juan se viste con ropa de su madre porque eso le hacía sentir cómodo: "En el cuarto de Jeanne encontré la apariencia justa: un vestido de baile, un collar de perlas y topacios, un maquillaje que preservó mi antigua piel" (p. 154).

Especial atención logra León de Warni, el padre de Juan, al jugar Musaraña:

León gozaba con borrar su nombre, con dejar de ser el hombre rico que era. Esto lo borraba, abolía el horrendo y deplorable destino de ser alguien que, más allá de toda impostura, pudiera reconocerse, estupefacto, a sí mismo. No era él, sino el reflejo de un ardor, escasamente era lo que alguna vez deseó ser, un fluido hermético y secreto, una intolerable voz que buscaba en las regiones exteriores el asidero de un semblante (1981: 30).

La máscara o disfraz en que se sumerge León, refleja la necesidad de escapar con absoluta libertad, al escoger lo que se representará, lo que responde a un deseo íntimo que se vive con festividad al gozar por un instante de ser otro distinto, lo que se le priva la mayoría del tiempo, hasta que un gesto o una señal cortaban el juego y todo volvía a la realidad de ser lo que no se quiere.

El juego de la Musaraña encarna el escape de la realidad, que coincide con lo que se desea ser ardientemente, con lo que se es en esencia, pero que se debe ocultar de los otros, esta sería la explicación a la naturalidad con la que se desarrolla el juego y se aceptan las imitaciones por parte de los participantes que no cuestionan la imitación, sino que la celebran como parte de un carnaval. Mientras que la realidad de la vida cotidiana es pura apariencia, en la medida que en ella se oculta lo que en verdad se quiere ser, lo que en verdad se es y se reprime. En otras palabras, en la actuación del juego de la Musaraña está la realidad; lo que remite nuevamente a la de inversión de la dicotomía de lo planteado desde el inicio: cazador/cazado, real/juego; esto es, la novela hace de la inversión un nudo central que hay que descifrar. 
La novela Ella o el sueño de nadie (1981) relata el triángulo amoroso entre Julián, Marcio y Reina, el texto presenta dos escenarios: el internado y el Circo. El internado es el lugar donde Marcio y Julián se conocen y mantienen una relación, Julián parece tener el control, ambos huyen, siendo acogidos por el Circo y por el entorno de Reina. La narración se centra en Julián quien siente una profunda atracción por Marcio, no obstante, esta atracción devuelve a la metáfora invertida del cazador y la presa, ya que Julián disfruta sodomizando a Marcio quien está profundamente enamorado de él, de este modo Marcio es una presa, pero que con el paso del tiempo, deja la posición de víctima, tomando el poder en la relación, para finalmente deshacerse de su antiguo victimario.

Nuevamente el texto remite a la inversión de la dicotomía cazador/presa, seductor/ seducido, donde aquel que en un principio ostenta el poder a medida que va siendo seducido por su presa va perdiendo el control, lo que lo sumerge en una profunda desazón.

Se inclina sobre los cabellos alborotados de Marcio y le toma la barbilla, la levanta él, viendo cómo el rostro que lloraba plácidamente se retuerce ahora en una mueca de dolor y vergüenza. La boca de Marcio se pliega y alarga y el sollozo estalla, incontenible. Julián baja del sillón hasta colocarse junto a él. Lo obliga a apurar el contenido del vaso; luego le toma la cabeza y lo atrae contra su pecho (1983: 35).

Ya no te temo porque ya no te amo; te he llevado a constatar por ti mismo tu mentira, esa muerte que miraste de reojo mientras fuiste capaz de eludirme. Pero siempre supe que pasarías por el lugar donde yo te estaba esperando. Me impacienté, claro, muchas veces. Estos diez años no han sido felices. Si reina discurriera, vería que han sido tres los rostros que se disputaban: uno el de su hermano, por su sangre; otro, el tuyo, por el amor; finalmente el mío, por las particularidades y las astucias del cálculo (1983: 112).

En cuanto a Reina, ella es la estrella del Circo, el objeto del deseo de muchos, la belleza perfecta que está profundamente enamorada de Julián, quien se esfuerza en vano por alcanzar el placer con ella, lo que lo conduce a una sensación profunda frustración.

El cuerpo anguloso de Julián la hace transitar por alturas ininterrumpidas, ya que él busca una satisfacción que no logra, permitiéndole a ella disolverse en una sucesiva marea de orgasmos, sólo detenidos por la impronta cotidiana del amanecer. El amor de Julián es espectacular, aunque muchas veces piensa que su enfermiza capacidad, su potencia que no amaina, la pone a ella misma en situación de desmedro (1983: 36).

Esta sensación de insatisfacción sumerge a Julián en un enorme vacío, que no logra satisfacer estando con Reina, pero que logra aminorar con el contacto con Marcio a quien imagina como una mujer. 
Julián se halla repasando los detalles de su fracaso (1983: 20).

Al igual que en Toda la luz del mediodía, el tema de la disyuntiva entre una relación homosexual y otra heterosexual forma parte de la trama central del texto, sin embargo, las escenas sexuales son descritas de maneras más explícita, aunque no por ello obscenas, nuevamente el autor logra entregar un relato altamente erótico con un lenguaje, alejado de lo referencial, lo que implica una ruptura, una escisión con las temáticas, ya que tal como lo plantea Bernardo Soria, el tema erótico escasea, lejos de ser el tema central es más bien un tema accesorio, un hecho más en el relato.

Finalmente, cabe volver a mencionar que esta novela es parte de la Colección la Sonrisa Vertical de la Editorial Tusquets, es decir, es un relato abiertamente erótico, sin eufemismos; lo que nuevamente permite volver a reafirmar la idea central del apartado: el carácter escisionista de su escritura, que no trepida en dar forma a un texto en que lo erótico masculino es el elemento central.

La última novela de Wacquez, Epifanía de una Sombra (2000), continúa en la misma línea escisionista de las novelas anteriores, ya que, por un lado, recrea la atmósfera de angustiosa intimidad de las experiencias de la juventud y la niñez que se representan en laberintos de recuerdos y, por otro, las relaciones entre los personajes marcados por el deseo imposible y los desencuentros. Aunque el narrador recrea las emociones de Santiago de Warni, desde la perspectiva de un niño y de un adolescente, acompañadas por las reflexiones filosóficas del Santiago sexagenario, se ofrece un resumen de la historia familiar: la juventud del padre de Santiago en Francia y su llegada a Chile desde Argelia. Además, hay indicios de la vida posterior de Santiago que iba a ser desarrollada en los dos tomos siguientes de la Trilogía que no alcanzaron a ser publicados.

Epifanía de una Sombra corresponde a la plenitud narrativa, a la madurez de su vida, mediante el montaje o entrelazamiento de flujos de escritura que obstaculizan la continuidad natural de los acontecimientos, mezclándose los espacios y los tiempos, creando un texto fragmentado, pero con sentido unitario de historia. Una de las primeras escisiones del texto corresponde al orden en que se narran los acontecimientos que no es cronológico, pero tampoco resulta del puro azar, sino que parece corresponder a un dejarse llevar por los recuerdos, surgiendo un cierto orden en la obra que tiende a desaparecer en sus últimas secuencias.

Los acontecimientos se desarrollan en dos grandes escenarios: uno de ellos es el espacio rural ficticio, el lugar de origen del protagonista, Nilhue, en la provincia de Colchagua, en el que transcurre su infancia y el conflictivo tránsito a la adolescencia. El otro es el espacio urbano, Santiago, la capital de Chile, al que llega a concluir sus estudios secundarios y da comienzos a su formación universitaria. 
Estos paisajes sirven de marco esplendoroso para la exhibición de la vida familiar y social, caracterizada, a primera vista, por la cordialidad y buena disposición, el amor severo, distante, protector, autoritario de los padres hacia los hijos; la sana convivencia, respetuosa de normas sociales y principios religiosos, el orgullo de clase, civilizado o en camino de serlo, los fuertes sentimientos de comunidad y pertenencia a la región.

Tal como en sus novelas anteriores, el despertar sexual abarca gran parte del texto, las prácticas amatorias son evocadas con gran precisión, pero evita, cuidadosamente, el lugar común grosero, el giro adocenado, las fórmulas hechas de la procacidad o el sensacionalismo truculento. En cuanto a la presencia constante del sexo en los adolescentes de esta novela, Epifanía de una sombra es una rotunda subversión o escisión a la supuesta castidad y falta de erotismo de la prosa chilena.

Las imágenes surgen aparentemente inconexas, en desorden, atadas a una cronología donde no es el tiempo el que mide a los actos, sino la relación que el mismo narrador establece entre los hechos, donde un recuerdo evoca a otro sin importar si la relación es clara o no para el lector, de este modo en la novela se tratan múltiples temas, por un lado, un hijo de terratenientes que crece más de lo apropiado, de la formación moral de un campesino demasiado familiarizado con el poder para desearlo y, por otro lado, se trata de la enfermedad y el placer, del desenfreno, de la voluntad del cuerpo, de la sumisión, la tiranía y la transgresión.

Epifanía de una sombra aparece dividida en un gran número de secciones, sin numeración ni títulos de capítulos, separadas por ornamentos tipográficos. Estas secciones recrean, sin orden cronológico, pero con una complejidad cada vez mayor, episodios de los primeros veinte años de la vida de Santiago de Warni.

Nuevamente, el relato asume el formato del Bildungsroman, pero al igual que Frente a un Hombre Armado, se hace de manera poco convencional, rompiendo con el molde de la novela de aprendizaje tradicional, lo que da lugar, nuevamente a una novela cuyo aprendizaje no es tal, sino un descubrimiento de la interioridad y de la aceptación de sí mismo, por parte del protagonista.

La recreación del pasado es hecha por un narrador adulto que escribe en tercera persona, dejando paso en raras ocasiones y de manera casi imperceptible a un comentarista-narrador en primera persona: "En casa de Reynaldo, su mujer, que antes había servido en las casas, los recibió con aquel amor que nunca he vuelto a conocer, abriendo su casa como una forma de abrir su corazón, su carne" (253). Estas sutilezas en la perspectiva narrativa, recuerda los mecanismos utilizados en su segunda novela, Paréntesis, donde la primera y la tercera persona oscilan a lo largo de toda la novela.

La novela parte con la escena de Santiago pilotando un Cessna, ahí empieza la remembranza de su niñez, la mentalidad de provincia, sus enfermedades, la relación con sus padres y el personal de servicio, la vida del interna- 
do, entre otros hechos, que marcan la vida del protagonista y que al igual que en el sobrevuelo, percibe su pasado de manera fragmentada, deteniéndose sólo en algunos episodios, sobre los que se explaya, en tanto que en otros prefiere callar y dejarlos pasar.

El sexo en Epifanía de una sombra es el de un adolescente que descubre su propio cuerpo, así como el de los otros. Otros episodios sexuales trascienden la curiosidad y la jactancia de un adolescente para evocar un mundo de horror, un mundo que corresponde a las dimensiones míticas de violencia, dominación y subyugación sexuales reflejadas de manera tan impresionante en Frente a un hombre armado:

El [Santiago] sentía los churretes de esperma bajándole por las piernas, aposándose en las baldosas, estaba lleno de coágulos y manchas oscuras y sentía, sin siquiera saber nada, que lo que acababa de ocurrir era un gran paso en el conocimiento, un peldaño que lo iniciaba en el trágico camino de lo milagroso (2001: 90).

Quiso morir, como también participar de aquel rito atroz (2001: 248).

Lo vio como un ente superlativo, como un arquetipo de lo bello, de lo bueno, de lo valiente. Allí, desarmado, sin ningún amparo, entregado a la violencia y al mal, no se defendía, entregaba su cuerpo joven a quien quisiera tomarlo (2001: 251).

Es mediante estas escenas que la novela establece su gran ruptura no sólo por el estilo de la narración, sino por incluir escenas sexuales entre hombres que van más allá de lo prohibido y lo violento, revelando el cambio profundo en Santiago, el descubrimiento, la Epifanía de su propia homosexualidad, de la que no se avergüenza y que lejos de esconderla, desea vivirla con total naturalidad y con pasión, aun cuando esto conlleve el costo de no ser aceptado. Es en este punto que creemos que la Epifanía de la Revelación se hace en el protagonista y en el texto, lo que posibilita configurar de manera más evidente nuestra hipótesis de Mauricio Wacquez como un escisionista, dado que él logra escribir un texto que no sólo rompe con el canon literario y las temáticas políticas de la época, sino, además irrumpe en la escena literaria con un tema que hasta hoy no logra encontrar su lugar, esto es, el erotismo.

La Oscuridad, en tanto, está profundamente arraigada en el protagonista y está relacionada con el mal, el deseo sexual, el inconsciente, lo irracional. Para él, las pasiones pertenecen al mundo de la oscuridad, ahí "El amor" es obsesivo: "las horribles obsesiones del amor" (2001: 12), doloroso: "Beatriz representaría la primera noticia del dolor puro, el medio eslabón que lo uniría a la nada, como un testimonio del amor desdichado" (2001: 24) y difícil: "Las alternancias de víctima y verdugo en una misma alma prueban lo fútil de las ideas que exigen comportamientos unívocos y dejan de lado los momentos en que en nuestro corazón nos entregamos a la sevicia o la protervia" (2001: 16). 
En conclusión, desde su primera novela Toda la Luz del Mediodía, hasta su última novela Epifanía de una Sombra e incluso hasta nuestros días, a partir de las múltiples relecturas, sus textos no han sido indiferentes a la crítica, captando la atención, ya sea por su temática o por su estilo. Mauricio Wacquez da lugar a un proyecto rupturista y subversivo, es decir, un proyecto escisionista, un proyecto de escritura, que al igual que su estilo no tiene parámetro ni seguidores, insertándose en la tradición literaria fuera de todo movimiento literario.

Es importante, recalcar que Wacquez percibe que el cambio en la percepción de la esfera cultural, dará paso a una incomprensión mayor de su proyecto, de modo que desde esta postura, que hemos denominado escionista, él puede plantearse como un escritor- personaje que se inserta en sus novela, mostrando un mundo hasta ese momento desconocido y oculto, el del amor homosexual, que es planteado como un elemento central en su escritura, en su vida y en su forma de plantearse en el mundo.

\section{Referencias bibliográficas}

A.E. Revista EVA, "Toda la Luz del Medio Día", Santiago, Nº1191, 23 de febrero, (1968): 69.

Amaro Castro, Lorena (2014). "Wacquez y sus precursores: infancia, género y nación". Revista chilena de literatura, (86): 31-50. Recuperado en 07 de agosto de 2015, de: http://www.scielo.cl/scielo.php?script=sci arttext\&pid=S071822952014000100002\&lng=es\&tlng=es.10.4067/ S0718-22952014000100002

Arana Freire, Elsa (2001). "Frente a un escritor armado. Entrevista Póstuma a Mauricio Wacquez" Suplemento Artes y Letras. El Mercurio, 25 de marzo de 2001: E10.

Avaria, Antonio (2000). "El tiempo Recobrado", El Mercurio, Santiago de Chile, 4 de Noviembre. Disponible en http://www.letras.s5.com/wacquez070102.htm (revisado 28 de julio del 2015).

BADRÉ, Fréderic (2003). L' avenir de la littérature. Paris: Gallimard.

Debord, Guy (2003). La Sociedad del Espectáculo. 1967. Valencia: Pre-textos.

Dendle, Brian (2002). "La última novela de Mauricio Wacquez: Epifanía de una sombra", en Revista chilena de Literatura, N60, pp. 87-99. Impreso.

EDWARDS, Jorge (1981). "Camino del exceso, tras la aparición de Frente a un hombre armado". El Mercurio, 30 de agosto de 1981: Disponible en http://www.letras.s5.com/wacquez110903.htm 
Fontaine Talavera, Arturo (2000). "Por lo gestero y Maromero". El Mercurio, 24 septiembre de 2000: disponible http://www.letra2.s5.com/wacquez02092.htm (revisado 28 de julio del 2015)

HouelleBecQ, Michel (2011). Intervenciones. Barcelona: Anagrama.

LunA, Roberto (1968). "Tendencias de la Novela Actual", La Prensa, Osorno, 7 de febrero de 1968: 22.

MARKs, Camilo (2003). "El poder y el deseo: Reedición de Frente a un hombre armado de Mauricio Wacquez", Revista de Libros El Mercurio 25 de Octubre: disponible en http://www.letras.s5.com/wacquez301003. htm (revisado 28 de julio del 2015)

Meyronnis, François (2000). L'Axe du Néant. Paris: Gallimard.

N.N. "Premio Barral de Novela 1974", Las Últimas Noticias, Santiago, 14 de septiembre, (1974): 4.

Rivas, Mauricio (2000). "Mauricio Wacquez La muerte es simple e irrefutable", El Metropolitano, 1 de septiembre de 2000: 22.

Robles, J. Francisco (2004). An-atomía/Desaparición del cuerpo en Excesos, de Mauricio Wacquez, en Revista Signos, 37(56): 105-121. Recuperado en 07 de agosto de 2015, de http://www.scielo.cl/scielo. php?script $=$ sci_arttext\&pid=S071809342004005600008\&lng=es\&tlng=es. 10.4067/S0718-09342004005600008

Ruiz-Tagle, Carlos (1975). "El Paréntesis de Mauricio Wacquez", Revista Qué Pasa, Julio: 35-37.

Simonetti, Pablo (2003). "La Rabia y el Descaro de Warni", en Suplemento Artes y Letras de El Mercurio, 23 de Noviembre de 2003: 11.

Simonetti, Pablo (2005). "Mauricio Wacquez: Prosista de materiales nobles". Revista de Libros de El Mercurio. 14 de enero de 2005: 15.

Simonetti, Pablo (2013). Presentación de la novela La soberbia juventud, GAM Santiago de Chile 1 de octubre de 2013.

Schopf, Federico (2001). La Liberación de los Sentidos, en El Mercurio, 25 de marzo de 2001: Disponible en http://www.letras.s5.com/wacquez110903.htm (revisado 28 de julio 2015)

SoriA, Bernardo (1985). "Mauricio Wacquez: Ella el sueño de Nadie", en El Mercurio de Valparaíso, 4 de Septiembre de 1985: 2.

VALDÉs, Adriana (1981). "Frente a un hombre armado", Revista Mensaje, No300. Disponible en http://www.letras.s5.com/wacquez270102.htm (revisado 28 de julio 2015).

Vattimo, Gianni (1987). El Fin de la Modernidad. Nihilismo y Hermenéutica en la cultura Posmoderna. Barcelona: Gedisa. 
Wacquez, Mauricio (1965). Toda la Luz del Mediodía, Santiago de Chile: Editorial Zig-Zag.

Wacquez, Mauricio (1972). Cultura como Seguridad, Santiago: Colección Escritos Breve del Departamento de Filosofía de la Universidad de Chile.

Wacquez, Mauricio (1975). Paréntesis, Barcelona: Barral Editores.

WacQuez, Mauricio (1981). Frente a un Hombre Armado. Barcelona: Bruguera.

WACQUEZ, Mauricio (1983). Ella o el sueño de nadie. Barcelona: Tusquets Editores.

Wacquez, Mauricio (2001). Epifanía de una Sombra. Santiago de Chile: Editorial Sudamericana.

Wacquez, Mauricio (2004). Hallazgos y Desarraigos. Santiago de Chile: Ediciones Universidad Diego Portales.

Zambra, Alejandro (2003). "Un embutido de obediencia de anarquía", en Hoja por Hoja, Las Ultimas Noticias, 12 de noviembre de 2003: 35.

ZAmBra, Alejandro (2007). "Un lector borrado", en La Revista de Libros. El Mercurio, 15 de abril de 2007: 13.

Zambra, Alejandro (2010). No Leer. Santiago: Ediciones Universidad Diego Portales. 
